\title{
Identification and characterization of microsatellite markers for the population genetic structure in endemic red-tailed barb, Gonoproktopterus curmuca
}

\author{
K. K. Musammilu • P. M. Abdul-Muneer • A. Gopalakrishnan • \\ V. S. Basheer · Harishankar Gupta • Vindhya Mohindra • \\ Kuldeep K. Lal • A. G. Ponniah
}

Received: 24 December 2013/Accepted: 13 January 2014/Published online: 28 January 2014

(C) Springer Science+Business Media Dordrecht 2014

\begin{abstract}
Gonoproktopterus curmuca is an endangered red tailed barb found in Southern part of Western Ghat, India. As a part of stock-specific, propagation assisted rehabilitation and management program, polymorphic microsatellites markers were used to study the genetic diversity and population structure of this species from the three River systems of Southern Western Ghats, such as Periyar River, the Chalakkudy River, and the Chaliyar River. From selected eight polymorphic microsatellite markers, the number of alleles per locus ranged from 2 to 8 , and the average number of alleles among 3 populations ranged from 5.0 to 5.75. The mean observed $\left(\mathrm{H}_{\mathrm{ob}}\right)$ and expected $\left(\mathrm{H}_{\mathrm{ex}}\right)$ heterozygosity ranged from 0.5148 to 0.5360 and from 0.5996 to 0.6067 , respectively. Significant deviations from Hardy-Weinberg Equilibrium expectation were found at majority of the loci (except Gcur MFW72 and Gcur MFW19) and in all three populations in which heterozygote deficits were apparent. The analysis of molecular variance indicates that the percent of variance among populations and within populations were 6.73 and 93.27, respectively. The pairwise $F_{S T}$ values between populations indicate that there were significant deviations
\end{abstract}

K. K. Musammilu · P. M. Abdul-Muneer $(\square)$.

A. Gopalakrishnan · V. S. Basheer

National Bureau of Fish Genetic Resources (NBFGR) Cochin

Unit, CMFRI Campus, Cochin 682 018, Kerala, India

e-mail: pmamuneer@gmail.com

H. Gupta · V. Mohindra · K. K. Lal · A. G. Ponniah

NBFGR, Canal Ring Road, P.O. Dilkusha,

Lucknow 226002, UP, India

Present Address:

A. G. Ponniah

Central Institute of Brackishwater Aquaculture, RA Puram,

Chennai 600028, Tamilnadu, India in genetic differentiations for the red-tailed barb populations from these three Rivers of the Western Ghats, India. The microsatellites methods reported a low degree of gene diversity and lack of genetic heterogeneity in the population of G. curmuca, which strongly emphasize the need of fishery management, conservation and rehabilitation of $G$. curmuca.

Keywords Red-tailed barb - Gonoproktopterus curmuca . Western Ghats Rivers · Microsatellites · Genetic diversity · Heterozygosity · Population genetic structure
Abbreviations
AMOVA Analysis of molecular variance
CAMP Conservation assessment management plan
CHD Chalakkudy River
CLR Chaliyar River
DNA Deoxyribo nucleic acid
F IS Coefficient of inbreeding or heterozygosity

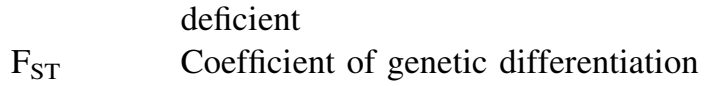
$\mathrm{H}_{\mathrm{ex}} \quad$ Expected heterozygosity
$\mathrm{H}_{\mathrm{ob}} \quad$ Observed heterozygosity
HWE Hardy-Weinberg equilibrium
IUCN International Union for Conservation of Nature and Natural Resources
$\mathrm{Na} \quad$ Number of observed alleles
NBFGR National Bureau of Fish Genetic Resources
NCBI National Centre for Biotechnology Information
$\mathrm{Ne} \quad$ Number of expected alleles
OD Optical density
PCR Polymerase chain reaction
PER Periyar River
UPGMA Unweighted pair-group method with arithmetic mean 


\section{Introduction}

Gonoproktopterus curmuca (Fig. 1) is a cultivable and ornamental freshwater fish belongs to Family Cyprinidae and is endemic to the rivers originating from southern part of biodiversity hotspot-the Western Ghats, India. In the study, we followed standard taxonomic references of the time [1-3] in assigning the name G. curmuca to specimens of a mid sized barb possessing 2 pairs of barbels, 41-43 scales in lateral series and with the caudal fin tips margined in red and black. Later, Menon and Rema Devi (1995) [4] named this species as Hypselobarbus kurali. Recently, Knight et al. (2013) have shown the red tailed barb from Peninsular India should rightly be named Hypselobarbus canarensis (Jerdon) [5].

G. curmuca is an omnivorous, gregarious species that normally lives in deep waters in the rivers of plains or in deep pools and shady parts in hilly regions [6]. The adults migrate to smaller tributaries and streams for spawning. It spawns in small streams with sandy and weedy bottoms. It is a bottom feeder and feeds mainly on algae and occasionally on insect larvae [2]. It is known to breed after the south-west monsoon months, from June to August [7]. The species enjoys a good market value as a food fish. Owing to its fast growth rate (maximum size $70 \mathrm{~cm}$ total length), it is one of the potential candidate species for aquaculture practices in the region. Its attractive colour makes it an ideal species for aquarium keeping in India and abroad. Over exploitation (especially for trade), destructive fishing methods that lead to habitat alteration, pollution, and related anthropogenic interventions in the natural habitats have considerably reduced the wild population of this species during the last few years [8]. The workshop of the Conservation Assessment Management Plan (CAMP) to evaluate the status of freshwater species of India, held at the National Bureau of Fish Genetic Resources (NBFGR) in 1997, categorized this species as critically endangered based on criteria of the International Union for Conservation of Nature and Natural Resources (IUCN) [9]. The species was finally short-listed as one of the candidates for stock-specific, propagation assisted rehabilitation and management programme in rivers where it is naturally distributed. In connection with this, NBFGR have been developed the captive breeding and milt cryopreservation techniques in this species. However, for a scientific stockspecific rehabilitation program, information on the stock structure and basic genetic profile of the species are essential and that is not available in case of G. ситтиса. In view of the above facts and reasons, the present work was taken up to discriminate the distinct populations of the species in areas of its natural distribution by using the microsatellites markers.

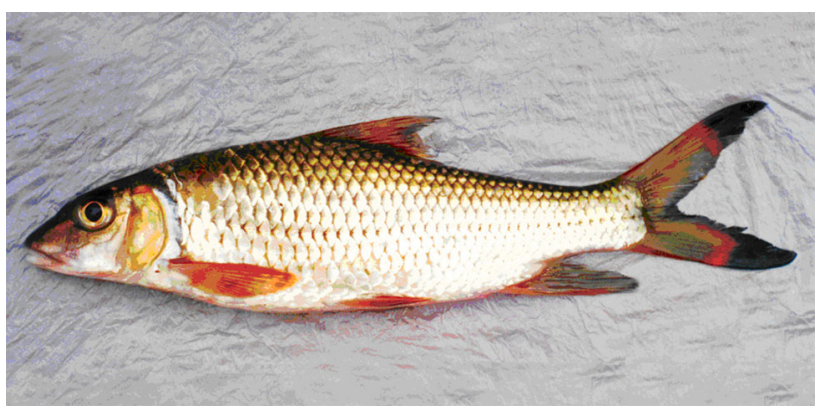

Fig. 1 The fish species, G. curmuca used for the present study

Microsatellites are polymorphic DNA sequences containing short tandemly arranged repetitions [10], distributed throughout the genome, and found in all prokaryotic and eukaryotic genomes [11]. Due to their high variability, these genetic markers have been widely used in genetic mapping [12] and population structure studies [13-16]. In our institute, we have been extensively studied these markers in several species including two species of yellow catfish, Horabagrus [17-20]; in Indian catfish, Clarias batrachus [21] and in Malabar Carp, Labeo dussumieri [22]. The present study involved in red-tailed barb, $G$. сигтиса, is the pioneer study of population genetics of one of the cyprinid from three riverine systems such as Periyar, Chalakkudy and the Chaliyar Rivers of the Western Ghats of India using polymorphic microsatellites markers.

\section{Materials and methods}

Fish samples and DNA isolation

Specimens of G. curmuca were obtained through commercial catches from the three Riverine systems viz; Periyar River (PER), Chalakkudy River (CHD) and Chaliyar River (CLR). A total of 70 individuals of $G$. ситтиса from each river of the Western Ghats Region were sampled. The collections sites are 1. Bhoothathankettu, Ernakulam, Kerala $\left(10^{\circ} 08^{\prime} 06^{\prime \prime} \mathrm{N} ; 76^{\circ} 39^{\prime} 40^{\prime \prime} \mathrm{E} ; 520 \mathrm{~m}\right.$ above MSL) of the PER 2. Athirampilly, Trichur, Kerala $\left(10^{\circ} 17^{\prime} 23^{\prime \prime} \mathrm{N} ; 76^{\circ} 32^{\prime} 49^{\prime \prime} \mathrm{E} ; 680 \mathrm{~m}\right.$ above MSL) of the CHD and 3. Manimooli, Nilambur, Malappuram, Kerala $\left(11^{\circ} 20^{\prime} 59^{\prime \prime} \mathrm{N} ; 76^{\circ} 18^{\prime} 39^{\prime \prime} \mathrm{E} ; 950 \mathrm{~m}\right.$ above MSL) of the CLR (Fig. 2). The species were identified by following the standard taxonomic references [1-3] with the help of expert taxonomists. The blood samples of $0.25 \mathrm{~mL}$ for DNA extraction were collected using minimal-invasive method from the live fish immediately after capture by puncturing the caudal vein, using sterile syringe rinsed with anticoagulant Heparin (1,000 units/1 mL; Biological E. Limited, India). The blood samples were immediately 
Fig. 2 Map shows the distribution of the sampling sites (*) of G. curmuca (Periyar River PER; Chalakkudy River $C H D$; and Chaliyar River $C L R$ )

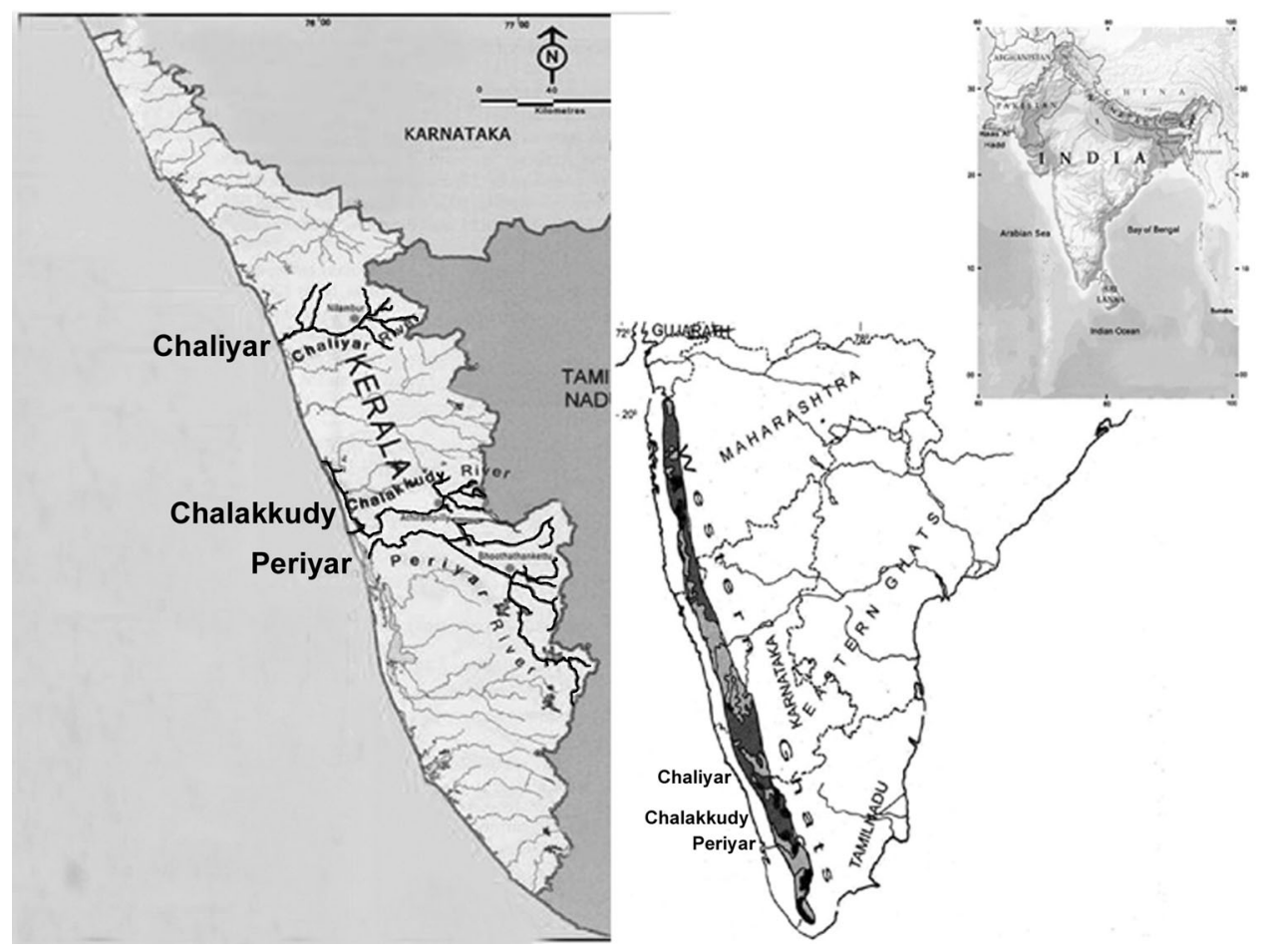

poured into a sterile $1.5 \mathrm{~mL}$ microfuge tubes containing $1.25 \mathrm{~mL}$ of $95 \%$ ethanol. To avoid clotting of blood in ethanol, the samples were thoroughly mixed; sealed using 'parafilm'; transported to the laboratory and then stored at $4{ }^{\circ} \mathrm{C}$ until DNA isolation. Total genomic DNA was extracted from blood samples following the procedures of Taggart et al., 1992 with minor modifications as mentioned in Abdul Muneer et al. [17, 23]. The quality and quantity of the extracted DNA was checked in UV spectrophotometer (Beckman, USA) by taking the optical density (OD) at 260 and $280 \mathrm{~nm}$. The quality was checked by measuring the ratio of absorbance at 260 and $280 \mathrm{~nm}(260 / 280)$.

\section{PCR Amplification and selection of microsatellite loci}

Available microsatellite information in the closely related species was collected from the GenBank (National Centre for Biotechnology Information (NCBI; www.ncbi.nlm.nih. gov). For cross-species amplification of microsatellite loci, a total of 40 microsatellite primers from Catla catla [24]; Cyprinus carpio [25, 26]; Barbodes gonionotus [27]; Campostoma anamalum [28]; Labeo rohita [29] and Pimephales promelas [30] were used (Table 1). The crossspecies amplification trials were done with eight specimens of $G$. curmuca and of the 40 primer pairs tested, 34 (85\%) provided successful amplification of homologous loci in $G$. ситтиса. These primers were again analyzed with larger sample size (30 individuals from 2 rivers) to evaluate their suitability (polymorphic pattern) in quantification of genetic divergence in G. curmuca. Several loci were monomorphic, few produced multiple products but 8 loci (Table 2) gave clear scorable products with 2-8 alleles per locus. These eight loci were finally analyzed to confirm the occurrence of repeats through cloning and sequencing.

Polymerase chain reaction (PCR) amplifications were performed in a $25 \mu \mathrm{L}$ reaction mixture containing $25 \mathrm{ng}$ DNA, 1X PCR buffer $(10 \mathrm{mM}$ Tris- $\mathrm{HCl}, 50 \mathrm{mM} \mathrm{KCl}$, $0.01 \%$ gelatin, $\mathrm{pH} 9$ and $1.5 \mathrm{mM} \mathrm{MgCl}_{2}, 200 \mathrm{mM}$ of dNTPs), 5 pmol of primers and $2 \mathrm{U}$ Taq DNA polymerase (Genei, Bangalore, India). The reactions were performed on a PTC 200 gradient thermal cycler (MJ Research Inc., MA, USA), and the PCR cycles were as follows: a predenaturation at $94{ }^{\circ} \mathrm{C}$ for $5 \mathrm{~min}$; followed by 25 cycles of denaturation at $94{ }^{\circ} \mathrm{C}$ for $30 \mathrm{~s}$, annealing at appropriate temperature (Table 2) for $30 \mathrm{~s}$ and elongation at $72{ }^{\circ} \mathrm{C}$ for $1 \mathrm{~min}$, and a final elongation at $72{ }^{\circ} \mathrm{C}$ for $2 \mathrm{~min}$. The PCR products were separated on $10 \%$ non-denaturing polyacrylamide gels using $1 \times$ TBE $(90 \mathrm{mM}$ Tris-borate and 2 mM EDTA, $\mathrm{pH}-8$ ) buffer ( $\mathrm{pH} 8)$ in the gel and reservoirs at $10 \mathrm{~V} / \mathrm{cm}$, at $4{ }^{\circ} \mathrm{C}$ in a cold chamber for $3-4 \mathrm{~h}$. The amplified microsatellite loci were visualized using silver staining (Amersham Pharmacia Kit) of the polyacrylamide gel. Molecular weights of the bands were calculated in reference to the molecular weight marker, $p B R 322$ DNA/ $M s p$ I digest (Genei, Bangalore, India) using the software Image Master ID Elite.

The microsatellite products were run and eluted from agarose gel and cloned into a TOPO TA cloning vector 
Table 1 Microsatellite primers of related species tested for cross-species amplification in Gonoproktopterus curmuca

\begin{tabular}{|c|c|c|c|c|c|}
\hline Sl. No. & Donor species & $\begin{array}{l}\text { No. of primer } \\
\text { pairs tested }\end{array}$ & Loci/primer & $\begin{array}{l}\text { Gene bank } \\
\text { accession no. }\end{array}$ & References \\
\hline 1 & Catla catla & 1 & CcatG1 & AF045380 & Naish and Skibinski [24] \\
\hline \multirow[t]{2}{*}{2} & Cyprinus carpio & 10 & $\begin{array}{l}M F W 01, M F W 02, \\
M F W 09, M F W 11, \\
M F W 15, M F W 17, M F W 19, \\
M F W 20, M F W 24, M F W 26\end{array}$ & - & Crooijmans et al.[25] \\
\hline & & 2 & $C C a 72^{\mathrm{a}}, \mathrm{CC} a 80$ & AY169249, AY169250 & Yue et al. [26] \\
\hline 3 & Barbodes gonionotus & 5 & $\begin{array}{l}\text { Bgon 22, Bgon } 69 \\
\text { Bgon } 75, \text { Bgon } 79 \\
\text { Bgon } 17\end{array}$ & - & Chenuil et al. [27] \\
\hline 4 & Campostoma anamalum & 9 & $\begin{array}{l}\text { Ca } 03, \text { Ca } 05, \\
\text { Ca } 06, \text { Ca } 08, \\
\text { Ca } 10, \text { Ca } 11, \\
\text { Ca } 12, \text { Ca } 16, \\
\text { Ca } 17\end{array}$ & $\begin{array}{l}\text { AF277575, AF277577, } \\
\text { AF277578, AF277580, } \\
\text { AF277582, AF277583, } \\
\text { AF277584, AF277588, } \\
\text { AF277589. }\end{array}$ & Dimsoski et al. [28] \\
\hline 5 & Labeo rohita & 6 & $\begin{array}{l}R 01, R 02, \\
R 03, R 05, \\
R 06, R 12\end{array}$ & $\begin{array}{l}\text { AJ507518, AJ507519, } \\
\text { AJ507520, AJ507521, } \\
\text { AJ507522, AJ507524. }\end{array}$ & Das et al. [29] \\
\hline 6 & Pimephales promelas & 7 & $\begin{array}{l}\text { Ppro } 48, \text { Ppro } 80, \\
\text { Ppro118, Ppro126, } \\
\text { Ppro132, Ppro168, } \\
\text { Ppro } 171\end{array}$ & $\begin{array}{l}\text { AY254350, AY254351, } \\
\text { AY254352, AY254353, } \\
\text { AY254354, AY254355, } \\
\text { AY254356 }\end{array}$ & Bessert and Ort [30] \\
\hline Total tes & & 40 & & & \\
\hline
\end{tabular}

${ }^{a}$ Primer sequence of $C C a 72$ reported by Yue et al. [26] was modified using PRIMER3 and renamed as $M F W 72$ in the present study

(Invitrogen, Carlsbad, USA). The recombinant bacterial colonies containing inserts were selected through PCR using respective microsatellite primers. The plasmids were isolated from the selected colonies and the presence of inserts re-confirmed though $0.8 \%$ agarose gel electrophoresis by comparing with insertless control vectors. Once recombinant plasmids were identified, the microsatellite inserts were sequenced using an ABI Prism 377 sequencer (Perkin Elmer, Norwalk, Conn.). The nucleotide sequences of confirmed microsatellites were deposited in NCBI GenBank (Accession No. DQ780014 and DQ780015 and EF582608-EF582613) (Table 2).

\section{Statistical analysis}

Indices of genetic diversity for populations, e.g. allele frequency, observed heterozygosity $\left(\mathrm{H}_{\mathrm{ob}}\right)$, expected heterozygosity $\left(\mathrm{H}_{\mathrm{ex}}\right)$, mean number of alleles per locus, $\mathrm{F}$ statistics, genotypic linkage disequilibrium and deviations from Hardy-Weinberg Equilibrium (HWE) were tested using open source software such as Genepop v3.1 [31] Genetix v4.05 [32], and Popgene v1.31 [33]. All results were adjusted for multiple simultaneous comparisons using a sequential Bonferroni correction [34]. Hierarchical partition of genetic diversity was evaluated by analysis of molecular variance (AMOVA) [35] using Arlequin v2 [36]. The expected frequencies of null alleles were estimated using MICRO-CHECKER v2.2.3 [37, 38] and all the genotypes of the loci with known inbreeding coefficient or fixation indices $\left(\mathrm{F}_{\mathrm{IS}}\right)$ were tested for null alleles and further analyzed for population differentiation. Unweighted pairgroup method with arithmetic mean (UPGMA) dendrogram was constructed by using Popgene v1.31 [33].

\section{Results}

Identification of the microsatellites

In red-tailed barb, out of 40 primers tried, only 8 primers gave scorable banding patters and produced 8 microsatellite loci viz., CcatG1-1, MFW1, MFW11, MFW19, MFW26, MFW72, Ppro48 and Ppro126 (Table 2). All the 8 loci were polymorphic (100\%) and applied in red-tailed barb for population genetic analysis. The 8 amplified loci were confirmed as microsatellites after sequencing. These loci further named as Gcur G1, Gcur MFW01, Gcur MFW11, Gcur MFW19, Gcur MFW26, Gcur MFW72, 
Table 2 Characteristics of polymorphic microsatellite loci in G. curтиса

\begin{tabular}{|c|c|c|c|c|c|c|c|c|c|}
\hline \multirow{2}{*}{$\begin{array}{l}\text { S1. } \\
\text { no. }\end{array}$} & \multicolumn{5}{|c|}{ Resource species } & \multicolumn{4}{|c|}{ Gonoproktopterus curтиса } \\
\hline & Species & Locus & Primer sequence $\left(5^{\prime}-3^{\prime}\right)$ & $\begin{array}{l}\text { Repeat } \\
\text { motif }\end{array}$ & $\begin{array}{l}\mathrm{Ta} \\
\left({ }^{\circ} \mathrm{C}\right)\end{array}$ & $\begin{array}{l}\text { Repeat } \\
\text { motif }\end{array}$ & $\begin{array}{l}\mathrm{Ta} \\
\left({ }^{\circ} \mathrm{C}\right)\end{array}$ & $\begin{array}{l}\text { No. of } \\
\text { alleles }\end{array}$ & $\begin{array}{l}\text { NCBI GenBank } \\
\text { accession } \\
\text { number }\end{array}$ \\
\hline 1 & Catla catla & CcatG1-1 & $\begin{array}{l}\text { F: AGCAGGTTGAT CATTTCTCC } \\
\text { R: TGCTGTGTTTCAAATGTTCC }\end{array}$ & $\begin{array}{l}\text { (GATA)n- } \\
(\text { CCA }) n\end{array}$ & 61 & (GGA)n & 51 & 7 & DQ780015 \\
\hline 2 & $\begin{array}{l}\text { Cyprinus } \\
\text { carpio }\end{array}$ & $M F W 1$ & $\begin{array}{l}\text { F: GTCCAGACTGTCATCAGGAG } \\
\text { R: GAGGTGTACACTGAGTCACGC }\end{array}$ & $(\mathrm{CA}) \mathrm{n}$ & 55 & (GT)n & 59 & 8 & DQ780014 \\
\hline 3 & $\begin{array}{l}\text { Cyprinus } \\
\text { carpio }\end{array}$ & $M F W 11$ & $\begin{array}{l}\text { F: GCATTTGCCTTGATGGTTGTG } \\
\text { R: TCGTCTGGTTTAGAGTGCTGC }\end{array}$ & $(\mathrm{CA}) \mathrm{n}$ & 55 & (GT)n & 58 & 8 & EF582608 \\
\hline 4 & $\begin{array}{c}\text { Cyprinus } \\
\text { carpio }\end{array}$ & $M F W 19$ & $\begin{array}{l}\text { F: GAATCCTCCATCATGCAAAC } \\
\text { R: CAAACTCCACATTGTGCC }\end{array}$ & $(\mathrm{CA}) \mathrm{n}$ & 55 & $(\mathrm{CA}) \mathrm{n}$ & 51 & 7 & EF582609 \\
\hline 5 & $\begin{array}{c}\text { Cyprinus } \\
\text { carpio }\end{array}$ & $M F W 26$ & $\begin{array}{l}\text { F: CCCTGAGATAGAAACCACTG } \\
\text { R: CACCATGCTTGGATGCAAAAG }\end{array}$ & $(\mathrm{CA}) \mathrm{n}$ & 55 & $(\mathrm{CA}) \mathrm{n}$ & 57 & 5 & EF582610 \\
\hline 6 & $\begin{array}{c}\text { Cyprinus } \\
\text { carpio }\end{array}$ & $M F W 72$ & $\begin{array}{l}\text { F: GCAGTGGCTGGCAAGTTAAT } \\
\text { R: GCACTACATCCACTGCACACA }\end{array}$ & (GATA)n & 55 & (GATA)n & 55 & 6 & EF582611 \\
\hline 7 & $\begin{array}{l}\text { Pimephales } \\
\text { promelas }\end{array}$ & Ppro48 & $\begin{array}{l}\text { F: TGCTCTGCTCTCCTGCGTGTCATT } \\
\text { R: CAGCCTCGGCGGTGTTGTTGC }\end{array}$ & $(\mathrm{TG}) \mathrm{n}$ & 60 & $(\mathrm{CA}) \mathrm{n}$ & 65 & 5 & EF582612 \\
\hline 8 & $\begin{array}{l}\text { Pimephales } \\
\text { promelas }\end{array}$ & Ppro126 & $\begin{array}{l}\text { F:CTGCGTGTCTGATAACTGTGACTG } \\
\text { R: GTCCCGGGACTTTAAGAAGGTC }\end{array}$ & $(\mathrm{CA}) \mathrm{n}$ & 60 & $(\mathrm{CA}) \mathrm{n}$ & 63 & 7 & EF582613 \\
\hline
\end{tabular}

Gcur Ppro48 and Gcur Ppro126. The nucleotide sequences of these loci were deposited in NCBI GenBank site (Accession numbers are given in Table 2). It was relatively easy to score the alleles at all loci of microsatellite, and subsequently eight loci were included in data analysis. The repeat units of each locus are given in Table 2.

Population genetic variation

All the eight confirmed microsatellite loci were further considered for population genetic analysis of $G$. curmuca. Among the three populations, we observed a total of 53 alleles in 8 loci with the number of alleles ranging from 2 to 8 per locus with a mean of 6.625 (Table 2). The highest number of alleles, eight, was expressed in Gcur MFW01 and Gcur MFW11 loci. The number of alleles and size of each microsatellite loci for each population are given in Table 3. The zymogram of locus Gcur Ppro48 is given in Fig. 3.

The observed heterozygosities $\left(\mathrm{H}_{\mathrm{ob}}\right)$ at all 8 polymorphic loci in the 3 populations ranged from 0.1143 in Gcur MFW11 of CHD to 0.7857 in Gcur MFW19 of Chalakkudy River, whereas the range of expected heterozygosities $\left(\mathrm{H}_{\mathrm{ex}}\right)$ was 0.2743 in Gcur MFW11 of CLR to 0.8037 in Gcur MFW19 of CLR (Table 4). There was no significant association indicative of linkage disequilibrium $(p<0.05)$ between any pair of microsatellite loci for any population $(p<0.05)$; therefore assumed that allelic variation at microsatellite loci was considered independent. The mean
$F_{\text {IS }}$ (Wright 1978), a measure of heterozygote deficiency or excess (inbreeding coefficient), was 0.137 in Periyar population, 0.152 in Chalakkudy population and 0.115 in Chaliyar population (Table 4). Almost all values of $\mathrm{F}_{\text {IS }}$ were significantly deviated from zero. The data show that most significant deviations were deficient for heterozygotes (Table 4).

Pairwise $\mathrm{F}_{\mathrm{ST}}$ and Hardy-Weinberg equilibrium (HWE)

The exact tests for fitness to HWE on all loci indicate that, MFW19 and MFW72 were found to be in HWE $(p>0.01)$, other loci significantly deviated from HWE $(p<0.01)$ (Table 2). The pairwise value of the coefficient of genetic differentiation $\left(\mathrm{F}_{\mathrm{ST}}\right)$ was estimated between populations (Table 5). The maximum $\mathrm{F}_{\mathrm{ST}}$, 0.0638, was shown between the Periyar and Chaliyar populations and the minimum, 0.04723, between the Periyar and Chalakkudy populations. The probability test revealed that the observed allele frequency in almost $50 \%$ loci in each population significant deviation $(p<0.05)$ from HardyWeinberg equilibrium after sequential Bonferroni correction. Pairwise comparison between riverine locations for microsatellite allelic heterogeneity in $G$. curmuca yielded significant deviations in frequencies after significance levels were adjusted for Bonferroni correction, except for Gcur MFW11 between Chalakkudy and Chaliyar ( $p=0.0596)$ and Gcur MFW19 between Periyar and Chalakkudy ( $p=0.4604)$ (Table 6). The results suggest 
Table 3 Observed (Na) and effective (Ne) number of microsatellite alleles in three riverine populations of G. curmuca

\begin{tabular}{|c|c|c|c|c|c|c|c|c|}
\hline \multirow[t]{2}{*}{ Locus } & \multicolumn{2}{|c|}{ Periyar River } & \multicolumn{2}{|c|}{ Chalakkudy River } & \multicolumn{2}{|c|}{ Chaliyar River } & \multicolumn{2}{|c|}{ Overall Populations } \\
\hline & $\mathrm{Na}$ & $\mathrm{Ne}$ & $\mathrm{Na}$ & $\mathrm{Ne}$ & $\mathrm{Na}$ & $\mathrm{Ne}$ & $\mathrm{Na}$ & $\mathrm{Ne}$ \\
\hline Gcur G1 & 7 & 3.2620 & 6 & 3.0948 & 6 & 2.3205 & 7 & 3.1024 \\
\hline Gcur MFW01 & 7 & 3.7209 & 6 & 3.2356 & 6 & 3.7559 & 8 & 3.9269 \\
\hline Gcur $M F W 11$ & 7 & 3.6199 & 6 & 3.0918 & 7 & 4.6715 & 8 & 4.8056 \\
\hline Gcur MFW19 & 7 & 4.1830 & 5 & 2.5417 & 7 & 3.1778 & 7 & 3.9895 \\
\hline Gcur $M F W 26$ & 5 & 3.9555 & 5 & 4.1078 & 4 & 4.0764 & 5 & 4.5312 \\
\hline Gcur $M F W 72$ & 5 & 2.2989 & 3 & 1.6385 & 4 & 1.9753 & 6 & 1.9679 \\
\hline Gcur Ppro48 & 3 & 3.0418 & 3 & 2.2207 & 4 & 2.6080 & 5 & 2.8271 \\
\hline Gcur Ppro126 & 5 & 2.5662 & 6 & 4.7548 & 5 & 4.3537 & 7 & 4.3869 \\
\hline Total & 46 & 26.648 & 40 & 24.685 & 43 & 26.939 & 53 & 29.538 \\
\hline Mean & 5.7500 & 3.3310 & 5.0000 & 3.0857 & 5.375 & 3.3674 & 6.625 & 3.6922 \\
\hline$\pm \mathrm{SD}$ & 1.4880 & 0.6644 & 1.3093 & 0.9994 & 1.3025 & 0.9981 & 1.2817 & 0.9739 \\
\hline
\end{tabular}

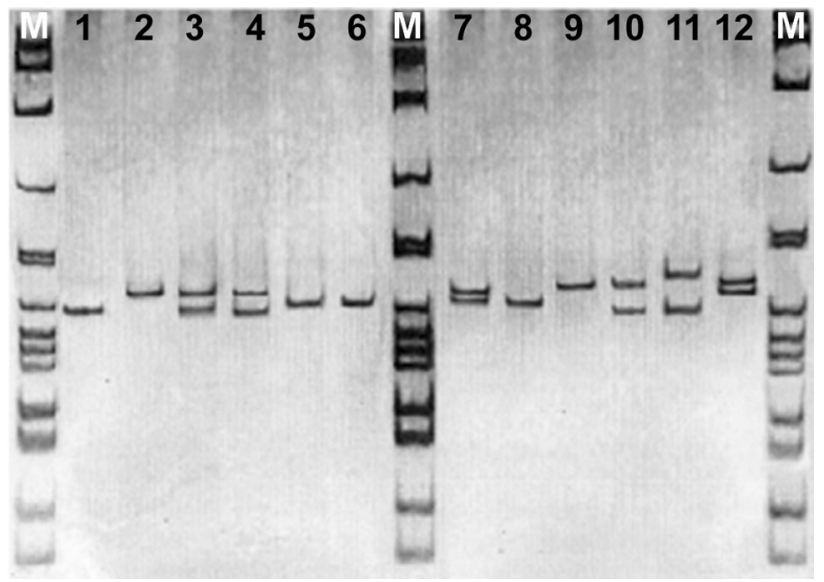

Fig. 3 Microsatellite pattern of locus Gcur Ppro48 in G. curmuca. Lanes 1-4 samples from Periyar river, 5-8 Chalakkudy River and 9-12 Chaliyar river. $M$ molecular weight marker (pBR322 with MspI cut)

that out of possible 24 pairwise combinations tests 22 were significantly deviated from HWE, suggesting low level of genetic differentiation between populations.

Private alleles and frequency of null alleles

We observed several private alleles, present only in a particular population of G. curmuca that can be used as stock-specific markers (Table 7). In microsatellites, nine private alleles were recorded, three each in Gcur MFW11 and two each Gcur MFW72, Gcur Ppro48 and Gcur Ppro126. In most cases, red-tailed barb populations from three rivers of the Western Ghats differed in frequencies of shared alleles. All pair-wise $\mathrm{F}_{\mathrm{ST}}$ statistics were significant, suggesting that all three population were significantly different from each other $(p<0.001)$ (Table 3$)$. The analysis of molecular variance on three populations (Table 8) indicates that most of the total variance $(93.27 \%)$ was attributed to the differences within the populations. Only a small proportion $(6.73 \%)$ of the variation was attributed to differences between the populations. The calculated frequencies of null alleles were assumed that null alleles may not be responsible for heterozygote deficiencies and significantly deviated from HWE (Table 9).

Genetic distance and relationships

On the basis of Nei's genetic distance [39] values and UPGMA dendrogram was constructed. The cluster values indicate the distinct relationships between the three populations of G. ситтиса. In this, based on Reynolds genetic distance, Periyar and Chalakkudy populations were clustered first, and then Chaliyar population was joined (Table 10; Fig. 4).

\section{Discussion}

The goal of this study was to determine whether the natural populations of endangered red-tailed barb, G. ситтиса from three riverine systems are genetically distinct. Such information is essential in stock restoration programs of the species for the safe use of brood stock from various geographic sources for captive breeding. The present study has generated important information on the genetic variation and stock structure of the red-tailed barb, endemic to the Western Ghats, India. Three genetically discrete stocks of the species have been identified for the first time using microsatellites markers and it is a significant step towards realizing the goal of management of fishery and conservation of populations of this cyprinid in the rivers of the Western Ghats region. The differentiation of a species into 
Table 4 Summary of genetic variation and heterozygosity statistics of eight microsatellite loci in Gonoproktopterus curmuca

\begin{tabular}{|c|c|c|c|}
\hline \multirow[t]{2}{*}{ Locus } & \multicolumn{3}{|c|}{ Populations ( $n=70$ each) } \\
\hline & Periyar & Chalakkudy & Chaliyar \\
\hline \multicolumn{4}{|c|}{ CcatG1-1 } \\
\hline Hob. & 0.3571 & 0.5310 & 0.5501 \\
\hline Hex. & 0.7976 & 0.7811 & 0.5308 \\
\hline $\mathrm{F}_{\mathrm{IS}}$ & +0.3292 & +0.2741 & -0.0370 \\
\hline $\mathrm{P}_{\mathrm{HW}}$ & $<0.0001 * * *$ & $<0.0001 * * *$ & 0.7863 \\
\hline \multicolumn{4}{|c|}{ MFW01 } \\
\hline Hob. & 0.5943 & 0.6927 & 0.5571 \\
\hline Hex. & 0.7652 & 0.6479 & 0.6604 \\
\hline $\mathrm{F}_{\mathrm{IS}}$ & +0.3344 & -0.0470 & +0.1631 \\
\hline $\mathrm{P}_{\mathrm{HW}}$ & $<0.0001 * * *$ & 1.0000 & $<0.0001 * * *$ \\
\hline \multicolumn{4}{|c|}{ MFW11 } \\
\hline Hob. & 0.3336 & 0.1143 & 0.2571 \\
\hline Hex. & 0.3261 & 0.2767 & 0.2743 \\
\hline $\mathrm{F}_{\mathrm{IS}}$ & -0.0123 & +0.4552 & +0.0931 \\
\hline $\mathrm{P}_{\mathrm{HW}}$ & 0.9867 & $<0.0001 * * *$ & 0.0842 \\
\hline \multicolumn{4}{|c|}{ MFW19 } \\
\hline Hob. & 0.7098 & 0.7857 & 0.7571 \\
\hline Hex. & 0.6894 & 0.7539 & 0.8037 \\
\hline $\mathrm{F}_{\mathrm{IS}}$ & -0.0193 & -0.0225 & +0.0676 \\
\hline $\mathrm{P}_{\mathrm{HW}}$ & 0.9862 & 1.0000 & 0.0741 \\
\hline \multicolumn{4}{|c|}{ MFW26 } \\
\hline Hob. & 0.3857 & 0.3180 & 0.3286 \\
\hline Hex. & 0.5291 & 0.4168 & 0.4321 \\
\hline $\mathrm{F}_{\mathrm{IS}}$ & +0.3748 & +0.2143 & +0.2827 \\
\hline $\mathrm{P}_{\mathrm{HW}}$ & $<0.0001 * * *$ & $0.0122^{*}$ & $<0.0001 * * *$ \\
\hline \multicolumn{4}{|c|}{ MFW72 } \\
\hline Hob. & 0.7429 & 0.7387 & 0.6014 \\
\hline Hex. & 0.6871 & 0.7236 & 0.5644 \\
\hline $\mathrm{F}_{\mathrm{IS}}$ & -0.0743 & -0.0254 & -0.0834 \\
\hline $\mathrm{P}_{\mathrm{HW}}$ & 0.8072 & 1.0000 & 0.7828 \\
\hline \multicolumn{4}{|l|}{ Ppro48 } \\
\hline Hob. & 0.6143 & 0.4802 & 0.5071 \\
\hline Hex. & 0.5949 & 0.5674 & 0.6098 \\
\hline $\mathrm{F}_{\mathrm{IS}}$ & -0.0318 & +0.3022 & +0.4316 \\
\hline $\mathrm{P}_{\mathrm{HW}}$ & 0.9517 & $<0.0001 * * *$ & $<0.0001 * * *$ \\
\hline \multicolumn{4}{|c|}{ Ppro126 } \\
\hline Hob. & 0.3714 & 0.5857 & 0.6271 \\
\hline Hex. & 0.4636 & 0.6282 & 0.6200 \\
\hline $\mathrm{F}_{\mathrm{IS}}$ & +0.1982 & +0.0685 & -0.0104 \\
\hline $\mathrm{P}_{\mathrm{HW}}$ & $0.0497 *$ & 0.8652 & 1.0000 \\
\hline \multicolumn{4}{|l|}{ Mean } \\
\hline \multicolumn{4}{|l|}{ Overall } \\
\hline \multicolumn{4}{|l|}{ Loci } \\
\hline Hob. & 0.5148 & 0.5360 & 0.5239 \\
\hline Hex. & 0.6067 & 0.5996 & 0.5619 \\
\hline $\mathrm{F}_{\mathrm{IS}}$ & - & - & - \\
\hline
\end{tabular}

Table 4 continued

\begin{tabular}{llll}
\hline Locus & \multicolumn{3}{l}{ Populations $(n=70$ each $)$} \\
\cline { 2 - 4 } & Periyar & Chalakkudy & Chaliyar \\
\hline An & 5.7500 & 5.0000 & 5.3750 \\
\hline
\end{tabular}

Hob observed heterozygosity, Hex expected heterozygosity, Fis inbreeding coefficient, $P_{H W}$ probability value of significant deviation from HWE, $A_{n}$ mean number of alleles per locus, * significant at $p<0.05, * * *$ significant after Bonferroni adjustment

Table 5 Pair-wise Fisher's $\mathrm{F}_{\mathrm{ST}}(\theta)$ between riverine samples of $G$. curmиса using microsatellite markers

\begin{tabular}{lll}
\hline Populations & Chalakkudy & Chaliyar \\
\hline Periyar & $0.04723^{* * *}$ & $0.06381 * * *$ \\
Chalakkudy & - & $0.05202 * * *$ \\
\hline
\end{tabular}

Significant after Bonferroni adjustment $(* * * p<0.0001)$

genetically distinct populations is a fundamental part of the process of evolution and it depends upon, physical and biological forces such as migration, selection, genetic drift, geographic barriers etc. Endangered species will have small and/or declining populations, so inbreeding and loss of genetic diversity are unavoidable in them. Since inbreeding reduces reproduction and survival rates, and loss of genetic diversity reduces the ability of populations to evolve to cope with environmental changes, Frankham [40] suggested that these genetic factors would contribute to extinction risk especially in small populations of threatened species. With the loss of a population/genetic stock, a species also loses its members adapted and evolved to survive in a particular habitat. Hence, conservation and fishery management strategy need to be stock-specific. The results of the present study pointed out the need to identify the most suitable conservation and management strategic plans for the genetically distinct populations of endangered G. curтиса.

Microsatellites are co-dominant markers and inherited in Mendelian fashion, revealing polymorphic amplification products helping in characterization of individuals in a population. Many features of microsatellites render them invaluable for examining fish population structure. Many microsatellite loci despite their extremely fast rates of repeat evolution are quite conservative in their flanking regions and hence can persist for long evolutionary time spans much unchanged. Due to this, primers developed for a species from the flanking regions of a microsatellite locus can be used to amplify the same locus in other related species [17]. Primers developed for a species by this method have been successfully tested for "cross-species amplification" or "cross-priming" in its related species in several teleosts, including Asian cyprinids [41-44] and it 
Table 6 Fisher's exact test of microsatellite allele homogeneity for all the population pairs of $G$. curmuca

\begin{tabular}{|c|c|c|c|}
\hline Locus & Population pairs & $p$ value (exact test) & SE \\
\hline \multirow[t]{3}{*}{ Gcur G1 } & CHL \& PER & $0.0061 *$ & 0.0002 \\
\hline & CLR \& PER & $0.0152 *$ & 0.0009 \\
\hline & CLR \& CHL & $0.0010^{*}$ & 0.0001 \\
\hline \multirow[t]{3}{*}{ Gcur MFW01 } & CHL \& PER & $0.0000 * * *$ & 0.0000 \\
\hline & CLR \& PER & $0.0000 * * *$ & 0.0000 \\
\hline & CLR \& CHL & $0.0000 * * *$ & 0.0000 \\
\hline \multirow[t]{3}{*}{ Gcur MFW11 } & CHL \& PER & $0.0022 *$ & 0.0003 \\
\hline & CLR \& PER & $0.0036 *$ & 0.0003 \\
\hline & CLR \& CHL & 0.0596 & 0.0012 \\
\hline \multirow[t]{3}{*}{ Gcur MFW19 } & CHL \& PER & 0.4604 & 0.0023 \\
\hline & CLR \& PER & $0.0261 *$ & 0.0000 \\
\hline & CLR \& CHL & $0.0030 *$ & 0.0003 \\
\hline \multirow[t]{3}{*}{ Gcur MFW26 } & CHL \& PER & $0.0092 *$ & 0.0006 \\
\hline & CLR \& PER & $0.0366 *$ & 0.0028 \\
\hline & CLR \& CHL & $0.0221 *$ & 0.0061 \\
\hline \multirow[t]{3}{*}{ Gcur $M F W 72$} & CHL \& PER & $0.0000 * * *$ & 0.0000 \\
\hline & CLR \& PER & $0.0000 * * *$ & 0.0000 \\
\hline & CLR \& CHL & $0.0000 * * *$ & 0.0000 \\
\hline \multirow[t]{3}{*}{ Gcur Ppro48 } & CHL \& PER & $0.0324 *$ & 0.0031 \\
\hline & CLR \& PER & $0.0000 * * *$ & 0.0000 \\
\hline & CLR \& CHL & $0.0000 * * *$ & 0.0000 \\
\hline \multirow[t]{3}{*}{ Gcur Ppro126 } & CHL \& PER & $0.0014 *$ & 0.0003 \\
\hline & CLR \& PER & $0.0000 * * *$ & 0.0000 \\
\hline & CLR \& CHL & $0.0364 *$ & 0.0024 \\
\hline Overall loci & Overall population & $0.0000 * * *$ & - \\
\hline
\end{tabular}

Significant at $* p<0.05$; significant at $* * * p<0.0001$ after sequential Bonferroni adjustment; PER Periyar River, CHL Chalakkudy River, CLR Chaliyar River, Markov chain parameters-dememorization: 1000, batches: 100 and iterations: 1,000

Table 7 Private alleles in microsatellite and their frequencies

\begin{tabular}{lllll}
\hline Locus & $\begin{array}{l}\text { Private allele size } \\
(\mathrm{bp})\end{array}$ & \multicolumn{3}{l}{ Allele frequency } \\
\cline { 3 - 5 } & & Periyar & Chalakkudy & Chaliyar \\
\hline Gcur & 168 & 0.0432 & - & - \\
MFW11 & 162 & - & - & 0.0176 \\
Gcur & 148 & - & - & 0.1287 \\
MFW72 & 138 & 0.2433 & - & - \\
& 134 & 0.2278 & - & - \\
Gcur & 226 & - & - & 0.1332 \\
Ppro48 & 218 & - & 0.0161 & - \\
Gcur & 170 & - & 0.1138 & - \\
Ppro126 & 162 & 0.1125 & - & - \\
\hline
\end{tabular}

was possible to obtain a set of useful markers for each study species by cross-priming. Recently, we have developed several microsatellite markers for the population genetic structure analysis by the cross-species of
Table 8 Analysis of molecular variance (AMOVA) based on microsatellite alleles in three populations of $G$. ситтиса

\begin{tabular}{llll}
\hline Sources of variation & $\begin{array}{l}\text { Variance } \\
\text { component }\end{array}$ & $\begin{array}{l}\text { Percentage of } \\
\text { variation }(\%)\end{array}$ & $\begin{array}{l}\text { Fixation } \\
\text { indices }\end{array}$ \\
\hline $\begin{array}{c}\text { Among populations } \\
\text { (among rivers) }\end{array}$ & $0.1954(\mathrm{Va})$ & 06.73 & $0.0673^{* * * *}$ \\
$\begin{array}{c}\text { Within populations } \\
\text { (within river) }\end{array}$ & $2.7097(\mathrm{Vb})$ & 93.27 & - \\
Total & $2.9051(\mathrm{Vt})$ & - & - \\
\hline$* * * p<0.0001 ;$ significance test after 1,000 permutations
\end{tabular}

amplification microsatellites in yellow catfish, Horabagrus [17-20] and in Malabar carp, Labeo dussumieri [22]. In the present study, altogether 40 primer pairs developed for six (resource) homologous fish species belonging to the Order Cyprinifonnes were evaluated for cross-species amplification of microsatellite loci in G. сигтиса. In G. сиrтиса, 9 amplified presumptive microsatellite loci were cloned and sequenced and among these, 8 loci were confirmed to contain microsatellites. Successful cross-priming was obtained with 8 primer pairs and all the 8 loci were polymorphic and ideal to be used as markers in stock identification studies. However, the optimum annealing temperature to get scorable band in G. curmuca slightly differed from that reported for the respective primer pair in the resource species. Cross-species amplification of primers of the Order Cypriniformes in G. curmuca shows the evidence of remarkable evolutionary conservation of microsatellite flanking regions (MFRs).

The tandem repeats of the microsatellite loci observed in the present study are comparable to that of the resource species. The GATA and CA repeats (MFW72; MFW01, MFW11, MFW19, MFW26, Ppro48 and Ppro26 primers) of the resource species, Cyprinus carpio and Pimephales promelas are exactly similar in G. сиrтиса, though the numbers of repeats varied. But, the GATA repeat of the microsatellite locus in Gcur Gl (resource species, Catla catla) differed in G. curmuca and replaced by GGA repeats. This can be due to the extremely fast rates of repeat evolution that may differ among loci, but keeping the highly conservative flanking regions unchanged, as reported by Zardoya et al. (1996) in cichlids and other Perciform fishes. The present study found GT and CA rich microsatellites abundant in G. curmuca which is in conformity with the published reports [45-49].

The low level of allele variation was observed in microsatellite loci in G. curmuca (Table 5). In comparison with the studies on European carp and Koi carp [25, 50], our data showed differences in the tandem repeat, number and/or size range of the alleles at the microsatellite loci. These were represented by the fact that the PER population had more alleles at all loci except for one/two locus 
Table 9 Summary statistics of null allele frequencies in G. curmuca

\begin{tabular}{|c|c|c|c|c|c|}
\hline \multirow[t]{2}{*}{ Locus } & \multirow{2}{*}{$\begin{array}{l}\text { Populations showing } \\
\text { positive } F_{I S} \text { values }\end{array}$} & \multicolumn{4}{|c|}{ Null allele frequency* (from MICRO-CHECKER) } \\
\hline & & Van Oosterhout & Chakraborty & Brooksfield1 & Brooksfield 2 \\
\hline \multirow[t]{2}{*}{ Gcur G1 } & Periyar & 0.0116 & 0.0095 & 0.0108 & 0.0108 \\
\hline & Chalakkudy & 0.0293 & 0.0278 & 0.0281 & 0.0281 \\
\hline \multirow[t]{2}{*}{ Gcur $M F W 1$} & Periyar & 0.0043 & 0.0038 & 0.0048 & 0.0048 \\
\hline & Chaliyar & 0.0163 & 0.0171 & 0.0188 & 0.0188 \\
\hline \multirow[t]{2}{*}{ Gcur $M F W 11$} & Chalakkudy & 0.0013 & 0.0014 & 0.0017 & 0.0017 \\
\hline & Chaliyar & 0.0025 & 0.0027 & 0.0032 & 0.0032 \\
\hline Gcur $M F W 19$ & Chaliyar & 0.0096 & 0.0077 & 0.0081 & 0.0081 \\
\hline \multirow[t]{3}{*}{ Gcur MFW26 } & Periyar & 0.0380 & 0.0414 & 0.0373 & 0.0373 \\
\hline & Chalakkudy & 0.0313 & 0.0402 & 0.041 & 0.0411 \\
\hline & Chaliyar & 0.0253 & 0.0189 & 0.021 & 0.021 \\
\hline \multirow[t]{2}{*}{ Gcur Ppro48 } & Chalakkudy & 0.0153 & 0.0145 & 0.0102 & 0.0102 \\
\hline & Chaliyar & 0.0104 & 0.0104 & 0.0201 & 0.0201 \\
\hline \multirow[t]{2}{*}{ Gcur Ppro126 } & Periyar & 0.0063 & 0.0058 & 0.0064 & 0.0064 \\
\hline & Chalakkudy & 0.0025 & 0.0023 & 0.0033 & 0.0033 \\
\hline
\end{tabular}

$* p<0.05$

Table 10 Nei's [39] genetic identity (above diagonal) and genetic distance (below diagonal) using microsatellite markers in G. curmu$c a$; geographical distances (in $\mathrm{km}$ ) are given in bracket

\begin{tabular}{llll}
\hline Populations & Periyar & Chalakkudy & Chaliyar \\
\hline Periyar & - & 0.9298 & 0.8285 \\
Chalakkudy & $0.0739(60)$ & - & 0.9003 \\
Chaliyar & $0.1764(220)$ & $0.1085(160)$ & - \\
\hline
\end{tabular}

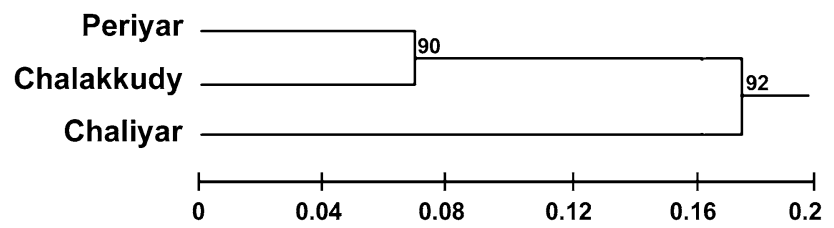

Fig. 4 UPGMA dendrogram based on genetic distance for three populations of red-tailed barb using eight microsatellite loci

comparing with the other two populations in study and with the original studies. The discrepancy in polymorphism could be due to different populations of red-tailed barb and microsatellite loci selected in these studies. Therefore, we were examined more individuals in the present study. Seventy individuals each from each population were utilized. In the present study, variations of allele sizes were quite low for Gcur MFW26, Gcur MFW72, and Gcur Ppro48 loci which might be due to their small number of repeat units and similar level of allele size variation is reported in many other freshwater teleosts and higher vertebrates [51-53].

The presence of heterozygote deficient individuals in the red-tailed barb populations could be due to null alleles. But, the analysis of data using MICRO-CHECKER indicated, occurrence of null alleles in all the 3 populations is very unlikely for the 7 primer pairs. Expected frequencies of null alleles were calculated in all the eight loci with high values, and heterozygote deficits were significant in the present study. This was supported by the absence of general excess of homozygotes over most of the allele size classes in MICROCHECKER analysis. In red-tailed barb, significant departures from HWE were found within samples across loci rather than within loci and across most samples. Such a situation is not consistent with null alleles [37]. Also, there was no instance of non-amplifying samples in repeated trials with any of the primer pairs in G. curmuca.

Surprisingly, for the red-tailed barb populations from the three largest freshwater rivers in Kerala of the Western Ghats region, although the populations are distinct, the observed heterozygosities were relatively low, which were represented by the significant departure from HWE at majority of microsatellite loci of all three populations. In another study on microsatellite diversity of Chinese common carp, deviation from HWE was also reported [54]. Several factors, e.g. null alleles, inbreeding and non-random sampling will lead to deviation from HWE [55]. A heterozygote deficit seems to be apparent in red-tailed barb from these three riverine systems, and heterozygosity may be more vulnerable to selection pressures and/or habitat changes. Although so far no historical data were available for genetic diversity and heterozygosity of red-tailed barb in this area, several reasons may result in departure of the microsatellite data from HWE expectation in these rivers of the Western Ghats. Firstly, heavy fishing pressure on the target species in these rivers may be one of the most 
important factors. Over-fishing is a severe problem during the past decades in India for unauthorized trade for aquarium keeping and this riverine habitat suffered from excessive exploitation and resources were severely declined [22, 56-60]. Extensive habitat alterations due to damming and deforestation, the proliferation of exotic species, and pollution, pesticides, and agrochemicals used in plantations are the other reasons. Tribes and forestdwelling communities along the basin are also highly dependent on the native species for their livelihoods. Destructive fishing practices are a serious concern for this species. Although red-tailed barb has high fecundity, which could compensate for the loss of mature individuals and expand into large populations from small population size in a few years, however, bottleneck effect may have happened if local extinction occurred. The introgression of cultured stocks due to floods and improper management of pond or cage farming may reduce both genetic variation and heterozygosity of natural populations. But till date, there is no report of introgression of cultured stock into these rivers.

In conclusion, it has been well recognized that habitat integrity and stability are important for fish, and some fish populations may be highly adapted to different freshwater environments. Human activities have been greatly changing the environments of fishes. The present study is the first attempt at the illustration of genetic structure of red-tailed barb in India. The markers and stock structure data generated in the present study can provide an essential component for formulating meaningful conservation strategies for red-tailed barb. This, along with the existing protocols on captive breeding and milt cryopreservation, small-scale aquaculture programs, and bans on destructive fishing practices can be integrated into a package for conserving genetic diversity and rehabilitation of the natural populations of G. curmuca.

Acknowledgments This study was financially supported by NATPICAR (MM-III-18) to AG. The authors are thankful to Dr. WS Lakra, Dr. MJ Modayil and Dr. SP Singh for encouragement, support and guidance.

\section{References}

1. Jayaram KC (1999) The freshwater fishes of the Indian Region. Narendra Publishing House, Delhi

2. Talwar PK, Jhingran AG (1991) Inland fishes of India and adjacent countries. AA Balkema, Rotterdam

3. Shaji CP, Easa PS, Gopalakrishnan A (2000) Freshwater fish diversity of the Western Ghats. In: Ponniah AG, Gopalakrishnan A (eds) Endemic fish diversity of the Western Ghats. NBFGRNATP Publication-1, National Bureau of Fish Genetic Resources, Lucknow, pp 33-55

4. Menon AGK, Remadevi K (1995) Hypselobarbus kurali (Pisces: Cyprinidae) a new large barb from the south western rivers of Peninsular India. J Bom Nat Hist Soc 92(3):389-393
5. Knight JDM, Rai A, D'Souza RKP (2013) On the identities of Barbus mussullah Sykes and Cyprinus curmuca Hamilton with notes on the status of Gobio canarensis Jerdon (Teleostei: Cyprinidae). Zootaxa 3750(3):201-215

6. Chhapgar BF, Manakadan R (2000) Ecology of Hill Streams of Western Ghats with special reference to fish community. US Fish and Wildlife Service \& Bombay Natural History Society, Bombay

7. Daniels RJR (2002) Freshwater Fishes of Peninsular India. Universities Press (India) Private Limited, Hyderabad

8. Musammilu KK (2006) Molecular genetic characterization of endemic endemic red: tailed barb, Gonoproktopterus curmuca (Hamilton: Buchanan, 1807). PhD Thesis, Cochin University of Science and Technology, Cochin, p 268

9. CAMP (1998) Conservation Assessment and Management Plan (CAMP) for freshwater fishes of India 1997. Zoo Outreach Organization (ZOO) and National Bureau of Fish Genetic Resources (NBFGR), Lucknow, India. Zoo Outreach Organization, Coimbatore, India, p 156

10. Tautz D (1989) Hypervariability of simple sequences as a general source for polymorphic DNA markers. Nucleic Acids Res 17:6463-6471

11. Litt M, Luty JA (1989) A hypervariable microsatellite revealed by in vitro amplification of a dinucleotide repeat within the cardiac muscle actin gene. Am J Hum Genet 4:397-401

12. Knapik EW, Goodman A, Ekker M, Chevrette M, Delgado J, Neuhauss S, Shimoda N, Driever W, Fishman MC, Jacob HJ (1998) A microsatellite genetic linkage map for zebrafish (Danio rerio). Nat Genet 18:338-343

13. Gupta A, Lal KK, Punia P, Singh RK, Mohindra V, Sah RS, Kumar R, Luhariya RK, Dwivedi AK, Masih P, Mishra RM, Jena JK (2013) Characterization of polymorphic microsatellite markers and genetic diversity in wild bronze featherback, Notopterus notopterus (Pallas, 1769). Mol Biol Rep 40(12):6625-6631

14. Kumla S, Doolgindachbaporn S, Sudmoon R, Sattayasai N (2012) Genetic variation, population structure and identification of yellow catfish, Mystus nemurus $(\mathrm{C} \& \mathrm{~V})$ in Thailand using RAPD, ISSR and SCAR marker. Mol Biol Rep 39(5):5201-5210

15. Matallanas B, Ochando MD, Alonso F, Callejas C (2013) Phylogeography of the white-clawed crayfish (Austropotamobius italicus) in Spain: inferences from microsatellite markers. Mol Biol Rep 40(9):5327-5338

16. An HS, Lee JW, Park JY, Jung HT (2013) Genetic structure of the Korean black scraper Thamnaconus modestus inferred from microsatellite marker analysis. Mol Biol Rep 40(5):3445-3456

17. Abdul-Muneer PM, Gopalakrishnan A, Musammilu KK, Mohindra V, Basheer VS, Lakra WS (2009) Genetic variation and population structure of endemic yellow catfish, Horabagrus brachysoma (Bagridae) among three populations of Western Ghat region using RAPD and microsatellite markers. Mol Biol Rep 36(7):1779-1791

18. Abdul-Muneer PM, Gopalakrishnan A, Sivanandan R, Basheer VS, Ponniah AG (2011) Genetic variation and phylogenetic relationships between two species of yellow catfish, Horabagrus brachysoma and $H$. nigricollaris using RAPD and microsatellite markers. Mol Biol Rep 38(4):2225-2232

19. Abdul-Muneer PM, Sivanandan R, Gopalakrishnan A, Basheer VS, Musammilu KK, Ponniah AG (2011) Identification and characterization of RAPD and microsatellite markers for genetic variation analysis in critically endangered yellow catfish, Horabagrus nigricollaris. Biochem Genet 49(1):83-95

20. Abdul-Muneer PM, Gopalakrishnan A, Musammilu KK, Basheer VS, Mohindra V, Lal KK, Padmakumar KG, Ponniah AG (2012) Comparative assessment of genetic variability in the populations of endemic and endangered yellow catfish, Horabagrus 
brachysoma (Hoarabagridae) based on allozymes, RAPD and microsatellite markers. Biochem Genet 50(3-4):192-212

21. Mohindra V, Singh A, Barman AS, Tripathi R, Sood N, Lal KK (2012) Development of EST derived SSRs and SNPs as a genomic resource in Indian catfish, Clarias batrachus. Mol Biol Rep 39(5):5921-5931

22. Gopalakrishnan A, Musammilu KK, Basheer VS, John L, Padmakumar KG, Lal KK, Mohindra V, Punia P, Dinesh K, Manjebrayakath H, Ponniah AG, Lakra WS (2009) Low genetic differentiation in the populations of the Malabar Carp Labeo dussumieri as revealed by allozymes, microsatellites and RAPD. Asian Fisher Sci 22(2):359-391

23. Taggart JB, Hynes RA, Prodohl PA, Ferguson A (1992) A simplified protocol for routine total DNA isolation from salmonid fishes. J Fish Biol 40:963-965

24. Naish KA, Skibinski DOF (1998) Tetranucleotide microsatellite loci for Indian major carp. J Fish Biol 53:886-889

25. Crooijmans RPMA, Bierbooms VAF, Komen J, Van der Poel JJ, Groenen MAM (1997) Microsatellite markers in common carp (Cyprinus carpio L.). Anim Genet 28:129-134

26. Yue GH, Ho MY, Orban L, Komen J (2004) Microsatellites within genes and ESTs of common carp and their applicability in silver crucian carp. Aquaculture 234:85-98

27. Chenuil A, Galtier N, Berrebi P (1999) A test of the hypothesis of an autopolyploid vs. allopolyploid origin for a tetraploid lineage: application to the Genus Barbus (Cyprinida). Heredity 82:373-380

28. Dimsoski P, Gregory PT, Mark JB (2000) Microsatellite characterization in central stoneroller Campostoma anomalum (Pisces: Cyprinidae). Mol Ecol 9:2187-2189

29. Das P, Barat A, Meher PK, Ray PP, Majumdar D (2005) Isolation and characterization of polymorphic microsatellites in Labeo rohita and their cross-species amplification in related species. Mol Ecol Notes 5:231-233

30. Bessert ML, Orti G (2003) Microsatellite loci for paternity analysis in the fathead minnow, Pimephales promelas (Teleostei: Cyprinidae). Mol Ecol Notes 3(4):532-534

31. Raymond M, Rousset F (1998) GENEPOP (ver. 3.1): a population genetics software for exact test and ecumenicism. J Hered $86: 248-249$

32. Belkhir K, Borsa $\mathrm{P}$, Chikhi L, Raufaste N, Bonhomme $\mathrm{F}$ (1996-2004) GENETIX 4.05, logicielsous Windows TM pour la génétique des populations. France. http://www.genetix.univmontp2.fr/genetix/genetix.htm

33. Yeh FC, Yang RC, Boyle T (1999) POPGENE 32: version 1.31. Population genetics software. Hyperlink http://www.ualberta.ca/ $\sim$ fyeh/fyeh/

34. Rice WR (1989) Analyzing tables of statistical tests. Evolution 43:223-225

35. Excoffier L, Smouse PE, Quattro JM (1992) Analysis of molecular variance inferred from metric distances among DNA haplotypes: application to human mitochondrial DNA restriction data. Genetics 131:479-491

36. Schneider S, Roessli D, Excoffier L (2000) Arlequin: a software for population genetics data analysis, version 2000. Genetics and Biometry Laboratory, Department of Anthropology, University of Geneva, Geneva

37. Van Oosterhout C, Hutchinson WF, Wills DPM, Shipley P (2004) MICRO-CHECKER: software for identifying and correcting genotying errors in microsatellite data. Mol Ecol Notes 4:535-538

38. Van Oosterhout C, Weetman D, Hutchinson WF (2006) Estimation and adjustment of microsatellite null alleles in non equilibrium populations. Mol Ecol Notes 6:255-256

39. Nei M (1978) Estimation of average heterozygosity and genetic distance from a small number of individuals. Genetics 89:583-590

40. Frankham R (2003) Genetics and conservation biology. C R Biol 326:S22-S29
41. Nazia AK, Siti Azizah MN (2014) Isolation of microsatellites in the bighead catfish, Clarias macrocephalus and cross-amplification in selected Clarias species. Mol Biol Rep. doi:10.1007/ s11033-013-2965-9

42. Huang W, Liang X, Qu C, Cao J, Zhao C, Cao L (2013) Development and characterization of novel polymorphic microsatellite loci in Siniperca scherzeri Steindachner and Siniperca chuatsi (Basilewsky). Mol Biol Rep 40(2):751-756

43. Chaturvedi A, Mohindra V, Singh RK, Lal KK, Punia P, Bhaskar R, Mandal A, Narain L, Lakra WS (2011) Population genetic structure and phylogeography of cyprinid fish, Labeo dero (Hamilton, 1822) inferred from allozyme and microsatellite DNA marker analysis. Mol Biol Rep 38(5):3513-3529

44. Chauhan T, Lal KK, Mohindra V, Singh RK, Punja P, Gopalakrishnan A, Shanna PC, Lakra WS (2007) Evaluating genetic differentiation in wild populations of the Indian major carp, Cirrhimis rrmgala (Hamilton-Buchanan, 1882): evidence from allozyme and microsatellite markers. Aquaculture 269(1/4):135-149

45. Na-Nakorn U, Taniguchi N, Nugroho E, Seki S, Kamonrat W (1999) Isolation and characterization of microsatellite loci of Clarias macrocephalus and their application to genetic diversity study. Fish Sci 65(4):520-526

46. Yang G, Xiao M, Yu Y, Xu S (2012) Genetic variation at mtDNA and microsatellite loci in Chinese longsnout catfish (Leiocassis longirostris). Mol Biol Rep 39(4):4605-4617

47. Neff BD, Gross MR (2001) Microsatellite evolution in vertebrates: inference from AC dinucleotide repeats. Evolution Int $\mathrm{J}$ Org Evolution 55(9):1717-1733

48. Watanabe K, Watanabe T, Nishida M (2001) Isolation and characterization of microsatellite loci from the endangered bagrid catfish, Pseudobagrus ichikawai. Mol Ecol Notes 1:61-63

49. Usmani S, Tan SG, Siraj SS, Yusoff K (2001) Isolation and characterisation of microsatellites in the Southeast Asian River catfish Mystus nemurus. Mol Ecol Notes 1:264-266

50. David L, Rajasekaran P, Fang J, Hillel J, Lavi U (2001) Polymorphism in ornamental and common carp strains (Cyprinus carpio L.) as revealed by AFLP analysis and a new set of microsatellite markers. Mol Genet Genomics 266:353-362

51. Abdul-Muneer PM (2006) Molecular genetic characterization of endemic yellow catfish, Horabagrus brachysoma (Gunther). PhD thesis, Cochin University of Science and Technology, Cochin, p 225

52. Carvalho GR, Hauser I (1994) Molecular genetics and the stock concept in fisheries. Rev Fish Biol Fish 4:326-350

53. Liu ZJ, Cordes JF (2004) DNA marker technologies and their applications in aquaculture genetics. Aquaculture 238:1-37

54. Zhou J, Wu Q, Wang Z, Ye Y (2004) Genetic variation analysis within and among six varieties of common carp (Cyprinus carpio L.) in China using microsatellite markers. Russ J Genet (Genet) 40:1144-1148

55. Castric V, Bernatchez L, Belkhir K, Bonhomme F (2002) Heterozygote deficiencies in small lacustrine populations of brook charr Salvelinus fontinalis Mitchill (Pisces, Salmonidae): a test of alternative hypotheses. Heredity 89:27-35

56. Gopalakrishnan A, Abdul Muneer PM, Lal KK, Mohindra V, Kapoor D, Ponniah AG (2006) Primers from the orders Siluriform and Osteoglossiform detect polymorphic microsatellite loci in sun-catfish, Horabagrus brachysoma. J Appl Ichthyol $22: 456-458$

57. Gopalakrishnan A, Abdul Muneer PM, Thomas PC, Lal KK, Mohindra V, Kapoor D, Ponniah AG (2006) Identification of allozyme markers for population structure analysis in yellow catfish, Horabagrus brachysoma (Gunther, 1864). Indian J fish 53(3):253-261

58. Abdul-Muneer PM, Gopalakrishnan A, Lal KK, Mohindra V (2007) Population genetic structure of endemic and endangered 
yellow catfish, Horabagrus brachysoma using allozyme markers. Biochem Genet 45(9-10):637-645

59. Abdul-Muneer PM, Gopalakrishnan A, Basheer VS, Lakra WS (2008) Identification of RAPD markers in endemic yellow catfish, Horabagrus brachysoma (Gunther, 1864). Asian Fish Sci 21: 293-304
60. Nagarajan M, Haniffa MA, Gopalakrishnan A, Basheer VS, Abdul-Muneer PM (2006) Genetic variability of Channa punctatus populations using randomly amplified polymorphic DNA. Aquac Res 37:1151-1155 